\title{
The Current Situation of Whampoa Military Academy Site in the Patriotic Education of Contemporary College Students
}

\author{
Zhiwu Zhou \\ Academy of Marxism, Guangdong University of Foreign Studies, Guangzhou, China \\ Email: 542921835@qq.com
}

How to cite this paper: Zhou, Z.W. (2018) The Current Situation of Whampoa Military Academy Site in the Patriotic Education of Contemporary College Students. Open Journal of Social Sciences, 6, 200-209. https://doi.org/10.4236/jss.2018.66018

Received: May 31, 2018

Accepted: June 23, 2018

Published: June 26, 2018

Copyright $\odot 2018$ by author and Scientific Research Publishing Inc. This work is licensed under the Creative Commons Attribution International License (CC BY 4.0).

http://creativecommons.org/licenses/by/4.0/

\begin{abstract}
Whampoa Military Academy is a new type of military school founded in 1924 by Sun Yat-sen with the help of the Communist Party of China (CPC) and the Soviet Union. It is the result of the first cooperation between the Kuomintang (KMT) and the Communist Party and has a far-reaching impact on the history of Chinese revolution and military. As an important patriotism education base, the Whampoa Military Academy Site plays a crucial role for Chinese people, especially college students. The base is divided into two parts in the patriotic education for college students: one is tourism education, the other is the cooperation with universities to carry out political education. This paper mainly conducts a research, then analyzes the current situation of the Whampoa Military Academy Site in contemporary student political education, finds out the existing problems and gives some advice.
\end{abstract}

\section{Keywords}

Whampoa Military Academy Site, Patriotic Education, Present Situation, Proposal, University Students

\section{Introduction}

\subsection{Whampoa Military Academy Site Overview}

The Whampoa Military Academy Site is located on Guangzhou's Cheung Chau Island and is a famous historical and cultural reserve in Guangzhou. It was established by Sun Yat-sen with the active support and assistance of the Communist Party of China and the Soviet Union. It was the result of the first cooperation between the KMT and the CPC. As the first military and political school to train revolutionary cadres in modern Chinese history, the Whampoa Military Acad- 
emy cultivated many outstanding students, who made tremendous contributions to China's revolution.

After the founding of New China, the once-glorious Whampoa Military Academy has become a historic site. In accordance with the principle of repairing old buildings, the old site of the repaired Whampoa Military Academy tried its best to maintain the unity of the surrounding environment and its own architectural style. The main exhibition buildings that are now restored and open to the audience include military school gates, school headquarters, Sun's monuments and memorial rooms, clubs, swimming pools, the Memorial Martyrs' Cemetery of East Conquer, the Northern Expedition Monument, Jishen Park, and Pavilion of Thinking and Teaching, and have a large number of collections like historical documents and photos.

\subsection{An Overview of the Patriotic Education of Whampoa Military Academy Site}

As a famous military and political school in history, the site of the Whampoa Military Academy takes a crucial responsibility of sharing the spirit of Whampoa and conducting patriotic education policy. The site of the Whampoa Military Academy educates people to be patriotic mainly in the form of exhibition visiting. The contents of the exhibition are basically the history of the Whampoa Military Academy, the review of the revolutionary history and the story of famous political and military officers.

The patriotic education of college students is of great significance to the country, and red tourism plays an important role in the ideological education of college students. The political education of college students on the site of Whampoa Military Academy is mainly divided into two aspects: one is spontaneous red tourism which means that college students visit the Whampoa Military Academy actively; the other is to cooperate with universities. For example, the universities mutually organize activities or programs in order to strengthen the political education of college students.

\section{Analysis of the Current Situation of Patriotic Education for College Students in Whampoa Military Academy Site}

Since the period of university life is crucial for the formation of students' attitude towards values, it is necessary for college students to understand the spirit of Whampoa. This is of great significance to the development of college students themselves and even the country. Therefore, we conducted online and offline surveys on the topic of Whampoa Military Academy's patriotism education effect for college students. We also did interviews with staff of the Academy.

280 online questionnaires were valid among 300 completed questionnaires. The respondents were mainly contemporary college students. On top of that, 50 offline questionnaires were completed. The respondents were mainly staff in the Academy and university students who visited Whampoa Military Academy. The results of the investigation are as follows. 


\subsection{The Masses Are the Object of the Exhibition Which Indicated That It Lacks of the Education Aimed at College Students. Although the Propaganda Method Can Keep up with the Fashion Trend, the Effect Is Not as Good as We Forecast}

According to the investigations and interviews with staff, we learn that Whampoa Military Academy Site mainly focuses on the masses rather than just students. It held exhibition annually and the themes of exhibition were different each year. When searching on the Internet, we can also find the themes in previous years such as "History of Sino-US Diplomacy", "War of Chinese Air Force", and "Whampoa Veteran's Handwriting Works". It also positively cooperated with other museums and memorial halls. The "Whampoa Military Academy and Anti-Japanese War" exhibition with the Korea Independence Memorial and the "The Communists and the Whampoa Military Academy" with Guangdong Revolutionary History Museum are some good examples of cooperation. These all demonstrate the contribution of the Whampoa Military Academy to patriotic education.

In the interview, we asked staff whether they had special advocacy methods to appeal young people, especially university students. The answer is no. They stated that Academy is a famous historical site. Hence, people will learn about relevant historical events both in daily life and in class. They considered the demand for tourism advertising among college students was not great.

At the same time, it can follow the fast changing new advertising methods. It has official Weibo, WeChat and Baidu tieba accounts. It insists on issuing new exhibition information and regularly updating the corresponding content even though the effect is general. Through the investigation of university students, more than $75 \%$ of students held view of so-so in terms of the display form and effect. They expressed that the display form was similar to other red tourism sites so it was not attractive. Nearly a third of the students said that the patriotic education of the Whampoa Military Academy Site has little effect on them (Figure 1).

Of the one-third of students, much of them stated that the effect was not good due to the lack of guide (Figure 2).

In the final part of the questionnaire, we simply asked what kind of patriotic education activities or curriculums their school had held. Some interviewees indicated that patriotism education in schools still did not have any effect on them. One of the important reasons was the lack of attractiveness.

\subsection{Whampoa Military Academy Site and Guangzhou Universities Have Cooperation, but Propaganda Is Not Enough, and the Effect Is Not Ideal}

In terms of patriotic education for college students, the Whampoa Military Academy has done a lot of work. In an interview with staff members, they told us that the Whampoa Military Academy site will recruit university students as volunteer instructors, and will also carry out activities related to college students, 


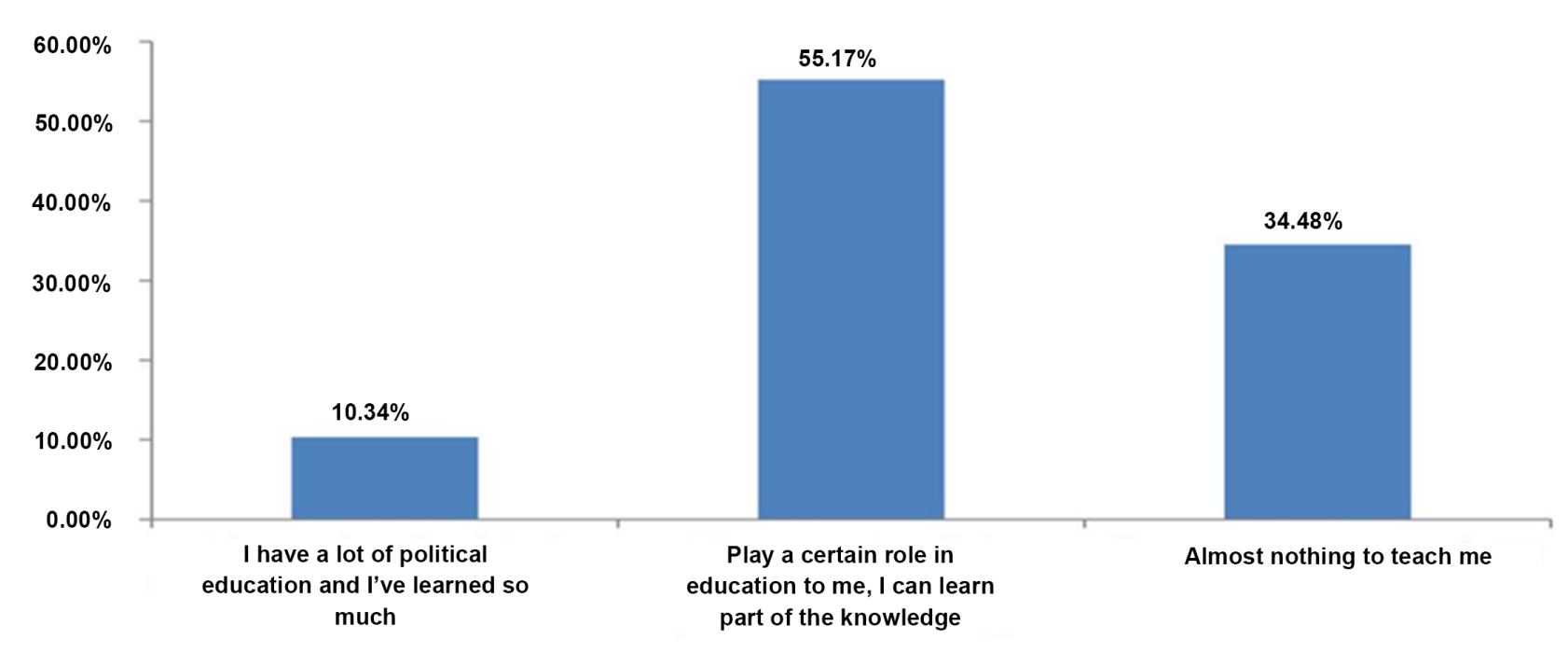

Figure 1. Influence on college students (nearly a third of the students said it nothing to teach me).

Without a guide, I can't understand fully.

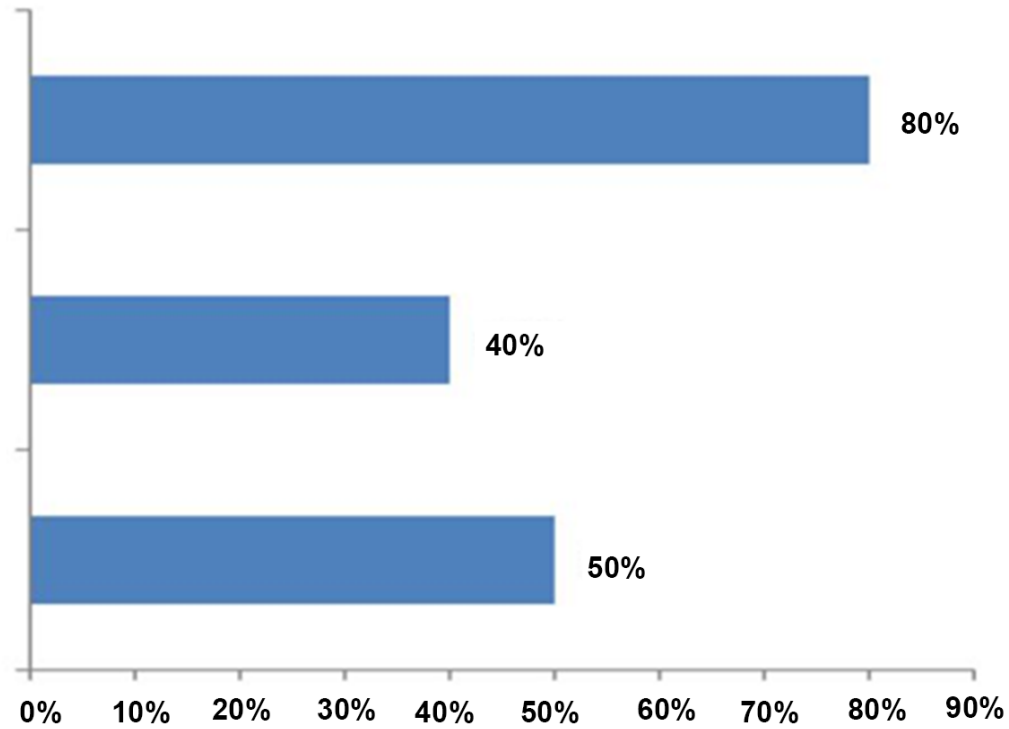

Figure 2. Cause ( $80 \%$ of the students think that no guide is the main reason).

such as the "Photography of the Whampoa Military Academy Museum Memorial Site Collection" activities for some time ago. Students use the camera to record the historical changes of the buildings in the area, reflecting the original intention of better maintenance of the site.

Whampoa Military Academy has also conducted certain cooperation with universities in Guangzhou. The "Taiwanese Tanabata" recitation activity was held in cooperation with Guangzhou University. The "Party Education Campaign" and "essay contest" were held with South China Normal University. The cooperation took place longer and deeper. It reached a joint agreement with the Guangdong University of Foreign Studies to establish a social base agreement for university students and a summer vacation project for the countryside. It is hoped that college students will be able to independently tell the history of the 
Whampoa Military Academy and give guidance to the tourists through certain training.

To this end, we conducted a related survey in University City. When we asked the students "whether they have heard of or participated in activities at the Whampoa Military Academy", more than half of the students said they had heard or participated in "visiting the military school base" and the "obligatory instructors" ranked second. It can be seen that in addition to the mainstream visits to the base, the "obligation interpreter" of the Whampoa Military Academy base has a certain degree of influence and popularity on the education of university students.

However, there are still more than $20 \%$ of students who do not know anything about this and said that they have not heard of any related base activities (Figure 3). This also shows that the Whampoa Military Academy has not done enough on the political education of university students and the effect is not satisfactory.

In addition, we decided to add a question to the questionnaire. What is the information about the Whampoa military academy base's cooperation with Guangdong University of Foreign Studies this year? We found that more than $60 \%$ of the students did not know the project because it is not much relationship between them (Figure 4). It can be seen that more students still have no interest in the patriotic education carried out by the school. This is an urgent problem to be solved.

\section{Reasons for the Problems in the Promotion of Patriotism Education to College Students in Whampoa Military Academy Site}

\subsection{Education Has a Single Way and No New Projects Have Been Developed}

According to the online and offline survey, one of the main reasons why the patriotic education of Whampoa Military Academy is not ideal for college students is that the education there has a single form. The education of Whampoa Military Academy base is simple and ordinary in form, which is basically a simple picture and text exhibition. And it makes college students lack of interest and lasting attention. When we asked the students how to improve the Whampoa Military Academy exhibition publicity, quite a few students put forward concrete advice to change the single traditional way of education and develop new activities to make it more interactive, then it can greatly enhance the students' interests.

\subsection{There Are Certain Defects in the Preservation and Repair of Cultural Relics and Insufficient Tourism Infrastructure}

There are some defects in the preservation and repair of relics in Whampoa Military Academy. According to the results of the interview, thirty percent of the respondents believed that the old site of Whampoa Military Academy was too 


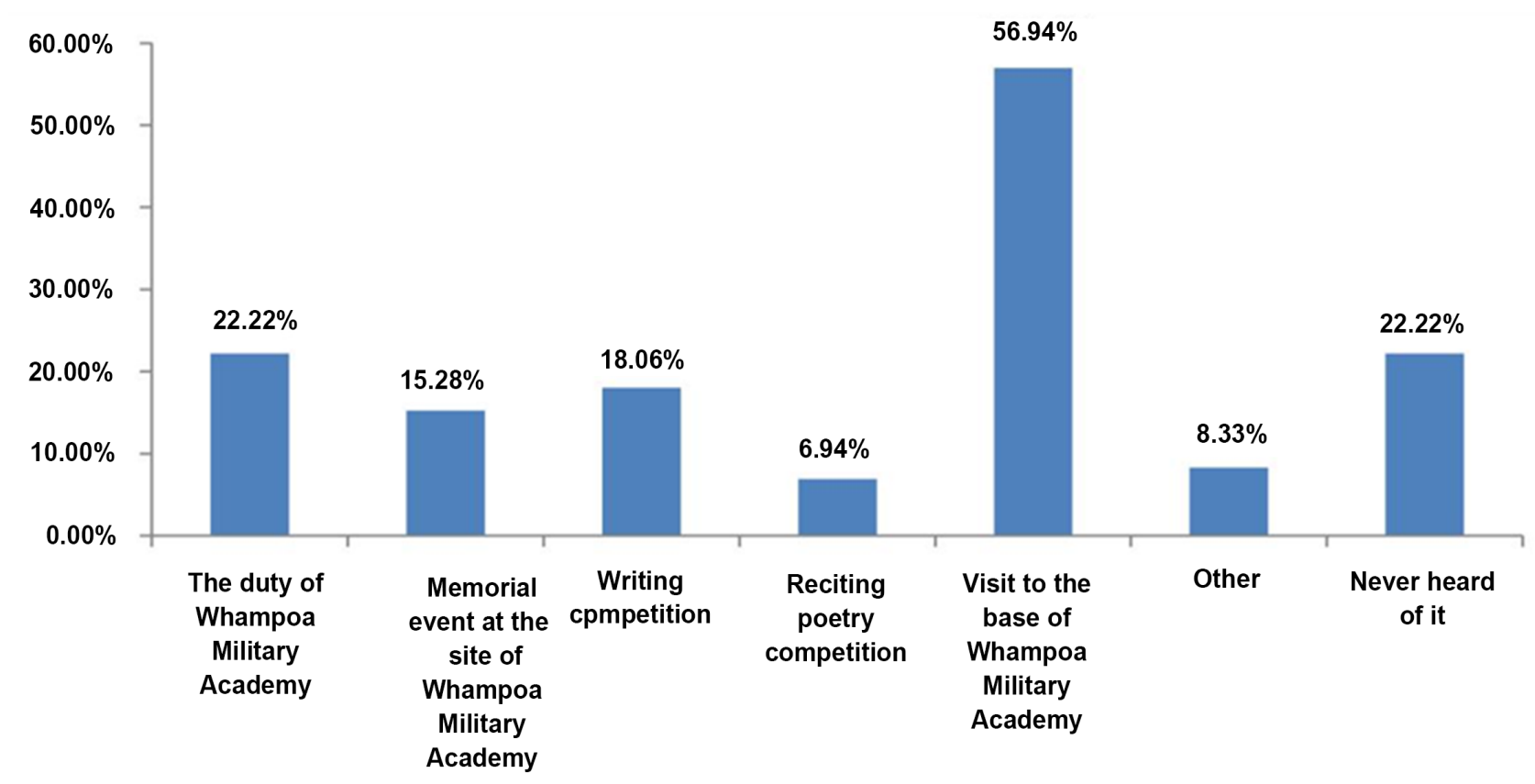

Figure 3. Know activities carried out (22.22\% of students do not know this).

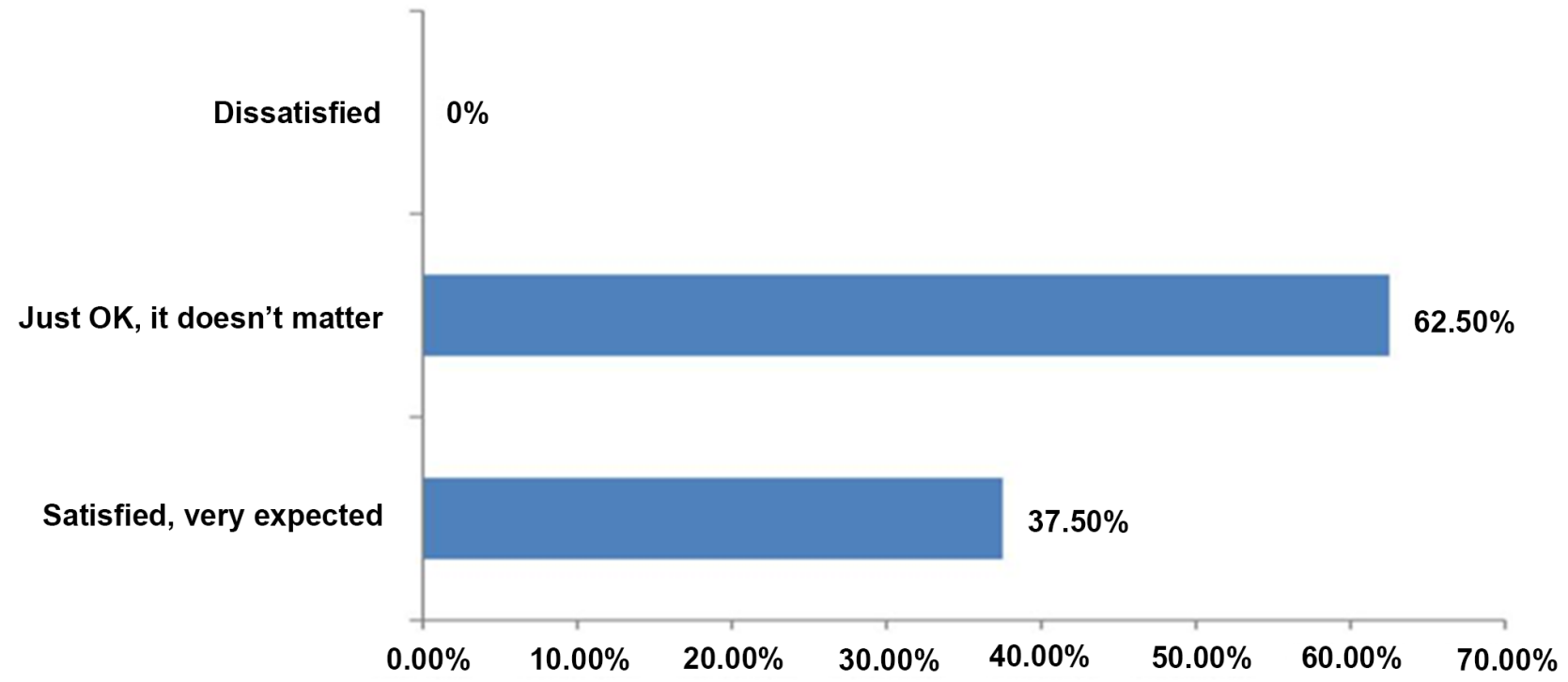

Figure 4. Know cooperation (62.5\% of the students think it not much relationship between them).

new and lacked a sense of history. Thirty percent believed that some of the relics in the old site of Whampoa Military Academy are damaged. "Try to keep the original scenery and cultural relics as much as possible" was also the choice of many students.

At the same time, the lack of basic tourism facilities also affected the impression of college students. For the perimeter of the Whampoa Military Academy site facilities construction, there are a part of interviewees said the diet, the transportation and the rest area construction are not ideal. To a certain extent, it reduced the tourists' travel experience. 


\subsection{Insufficient Publicity for College Students and Insufficient Free Explanation of Tour Guides}

Although Whampoa Military Academy closes to the Guangzhou University Town and has natural geographical advantages, but not enough publicity has been done in the campaign against college students' patriotism education. It is a very good description that most of the students did not go there to visit. Although it has some cooperation with some universities in Guangzhou, students' general knowledge and enthusiasm for participating in such activities are not high.

Whampoa Military Academy site visit is free and also not set other fees, but there is also no regular free interpretation of the guide. It has caused many student can't understand the meaning of the patriotism education deeply.

\subsection{College Students Themselves Are Not Interested in Political Education}

Visited from the Whampoa Military Academy of the respondents in the survey, about $50 \%$ of the students said the purpose of the visit to the Whampoa Military Academy is to study and investigate, and there are nearly half of students said they went to review the history and admire Whampoa spirit and the spirit of Sun Yat-sen. It explained that Whampoa Military Academy-this patriotism education base still has a certain appeal for college students.

Whampoa Military Academy is very famous, but college students are not very interested in this kind of patriotic education. They are not very willing to come to visit and only to hear about it. According to the field investigation, we found that not many college students came to visit the old site of Whampoa Military Academy. In addition, students generally reject the activities or contents of education related to red thoughts, and have low acceptance of education related to school. This is a very important reason to pay attention to.

\section{Suggestions on Improving the Patriotic Education of University Students in Whampoa Military Academy Site}

\subsection{Increase Government Support and Improve Tourism Infrastructure}

As a red patriotism education base and close to the Guangzhou University Town, the Whampoa Military Academy has an inherent advantage in fostering patriotic education for college students. However, in implementing this education, the government needs to increase its financial and human resources to carry forward the red tourism gene, strengthen the red tourism education function, and increase the vitality of red tourism [1].

In view of the hardware issues of scenic spots, the old site of the Whampoa Military Academy must always adhere to the principle of repairing the old, and maintain the original appearance and historical atmosphere of the scenic spot. Appropriately increase the number of leisurely entertainment places and choose 
a fixed location to develop small meals and rest places. This will help improve the students' visiting experience and make it easier for college students to receive patriotic education in scenic spots.

\subsection{Optimize Educational Resources and Strengthen Staff's Quality Training}

Red resources are full of touching revolutionary stories. It has a strong appeal and appeal for college students [2]. Based on the original cultural relics, the Whampoa Military Academy should deeply explore the functions of ideological and political education, accurately and truly reproduce the historical resources, and highlight its modernity and modernity. For example, the "China Air Force's Anti-Japanese War Memory Exhibition" currently being held at the Whampoa Military Academy Base, the Air Force hero story at the exhibition, and a letter of the Air Force Warrior reflect its good use of educational resources. These stories and books can easily transform passive education into active education, which is very helpful to improve the patriotism of college students.

It is necessary for education and propaganda to require people to complete, improve the quality of staff, and increase their enthusiasm for work. This requires perfecting the staff training mechanism and strengthening the quality training of staff, especially the training of personnel [3]. The lecturers in the museum are not enough. They can recruit university student volunteers and train more university volunteer instructors.

\subsection{Use a Variety of Ways to Improve Education and Education}

For the single issue of scenic spots, Whampoa Military Academy's former site can learn effective training methods for the "Zuoyi Conference Site". The exhibition hall introduces advanced light and shadow technology to reproduce the scene of the "Zunyi Conference", giving educators a sense of immersion in their studies [4]. At the same time, in the new museum also added a data search area, multimedia interactive experience area, I believe this has a great reference for the solution of the traditional education form of the Whampoa Military Academy. Combining light and shadow technology and even VR technology to restore the past scenes, etc., through new technology means to meet the development trend of the times, so that education shows a vivid image, useful and profound.

At the same time, the former site of the Whampoa Military Academy can be appropriately increased in some forms of education, and some new activity programs are regularly held, such as listening to a military academy's military education classes, to make activities more diverse.

\subsection{Strengthen Cooperation with Colleges and Universities in Various Universities and Organize Various Activities}

Cooperating with universities in patriotic education is a win-win model. It is suggested that many scenic spots in the old site of the Huangpu Military Academy should be further in-depth cooperation with major universities, and the 
cooperation partners may be different, and the cooperation methods may be diverse.

In cooperation with colleges and universities, the students of the School of Collective Organizations visited and adopted the method of "learning middle school and traveling to middle school" to avoid boring preaching and cater to the aesthetic and interest orientation of college students. At the same time, students' patriotic education can also be strengthened through the establishment of a practice base [5].

In cooperation with the student union of the League Youth League Committee, organize some activities, establish reward mechanisms, and encourage college students to participate actively. Like photography competitions, poetry recitations, etc., to attract students interest, play a role in allowing students to change the negative attitude towards the red patriotic education.

Collaborate with college red societies. Red colleges and universities in colleges and universities are people's images of the ideological and political theory societies organized by voluntary organizations organized by college students [6]. The associations conduct independent red events such as red tourism, research, discussion and learning. The red community has stronger student interaction and participation than the traditional school teaching department. Compared with the classroom instillation, the social activities based on student interest have more obvious educational effects. Therefore, for the cooperation between military academies and universities, the red community is undoubtedly a very good media bridge. With the deepening of cooperation, the Red Societies may even directly become the carrier of the Huangpu Military Academy to hold relevant patriotic red education activities for college students. Compared with the rigorous and formal school sector, the relaxed atmosphere of the red community will have greater interest and freedom for students to participate in patriotic red activities. At the same time, red universities in the universities will be able to better undertake the political education cooperation project of the Huangpu Military Academy in their own universities: responsibility for publicity, more specific docking campaigns and event planning.

\section{Summary}

In general, we learn that the Whampoa Military Academy Site is really actively engaged in patriotic propaganda and education from the investigation. It realizes the strength and potential of the new media, pays attention to the patriotic education of college students and promotes active cooperation with some colleges and universities in Guangzhou. However, the propaganda is still not enough with unsatisfactory result. There are many reasons for this situation. It has its own subjective reasons, such as a single form, not rich contents, and other objective reasons, such as lack of interest among college students. To improve the support of the government, to learn from the excellent experience of his library, to change the way of its own propaganda, to increase cooperation with colleges and universities, and so on, can improve its role. 


\section{References}

[1] Xiao, L. (2014) Research on Red Culture Education of Contemporary College Students. Nanjing Normal University, Nanjing.

[2] Jin, M.H. (2014) The Combination of Red Tourism and Ideological and Political Education for University Students: A Case Study of Yanbian Red Tourism. Yanbian University, Yanji.

[3] Tan, F.F. (2013) On the Value of Red Tourism in Ideological and Political Education for College Students and Its Approaches to Realization. Hubei University, Wuhan.

[4] China News (2014) Advance of Advanced Lighting Technology to Reproduce the History of Zunyi Meeting Site. China News.

[5] Huang, X. and Hu, S. (2009) Special Value of Red Resources in Optimizing the Efficiency of Ideological and Political Education in Colleges and Universities. Literary Circles of CPC History, 7, 67.

[6] Li, C.C. and Sun, W.A. (2012) The Construction of Red Societies in Colleges and Universities and Ideological and Political Education for University Students. Guide Journal of Ideological and Theoretical Education, 5, 110. 